Tér és Társadalom 21. évf. 2007/2. 127-132. p.

Tér és Társadalom

XXI. évf. 2007 2: 127-132

KITEKINTö

\title{
A TÜNDÉRMESE, MINT AZ ALTERNATÍV TURIZMUSFEJLESZTÉS EGY ESZKÖZE: GÖRÖGORSZÁG PÉLDÁJA
}

\section{(Fairytale as a Tool of Development of Alternative Tourism: the Example of Greece)}

\section{ANESTIS FOTIADIS}

Kulcsszavak:

turizmus mese Görögország

A rurális turizmusfejlesztés és a tündérmesék között összefüggés van. A mesék ugyanis közelebb hozzák a gyerekeket a vidéki területekhez, ezáltal pozitivan befolyásolva óket a késöbbi alternativ turizmusban való részvételük terén. Sokunk szerette meg a spenótot, miután megnézte a "Popey a tengerész" cimü mesét. Ebben a cikkben arra próbálunk rávilágítani, miért és hogyan járul hozzá a mese az alternativ turizmus fejlódéséhez; másrészrôl pedig arra, miért és hogyan segíti az alternativ turizmus az embereket a képzeletbeli mesevilágok megjelenitésében.

\section{Bevezetés}

Folyamatosan változó pénzügyi, kulturális és szociális környezetben élünk. $\mathrm{Az}$ alsó- és középrétegek pénzügyi lehetőségeinek folyamatos változása, valamint a megerősítési célzattal létrehozott változások - sok országban új prioritásokat eredményeztek néhány alacsonyabb gazdasági réteg tekintetében. „A makroökonómiai csoportok sima ösvénye alatt létezik egy nagyon aktív mikroökonómiai világ. A termelési tényezők egy állandó és erőteljes újraelosztása zajlik." (Ács 1999)

Görögország (a maga 11 millió lakosával) régóta világosan látja, hogy a turizmus a legfontosabb bevételi forrása. A modern társadalmakban a turizmus mindig is meghatározó szerepet játszott, mostanára a szabadidő eltöltésének, az emberi, a gazdasági és kulturális kapcsolatok építésének legnépszerúbb formájává vált. (Michalkó 2000). Hosszú évek fejlesztő munkája járult hozzá a turisztikai kapacitás erősítéséhez. Így Görögország a tömegturizmus igényeinek kielégítése irányába fejlödött, mely tevékenység előbb virágzott, majd évek múlva visszaesett.

A szervezett turizmus modellje a hetvenes évek végétől egyre inkább hanyatlott, mivel komoly problémákat (szociális, környezeti, kulturális) eredményezett több turisztikai célpont esetében, föleg a fejlődő területeken. 
A turizmusnak egy másik ága fejlődött ki, amely jobban reflektál a különböző fejlődési megközelítésekre, szabadabb és sokkal egyénibb. A mennyiség helyett sokkal inkább a minőségre helyezi a hangsúlyt, és a turisták speciális érdeklődési köreire támaszkodik (vallás, sport, képzés).

A turizmus speciális fajtái azok, melyeket az a különleges érdeklödési kör határoz meg, amely adott területre vonzza a turistákat.

Az új turizmus modell a turizmus fejlesztés új kulcspontjaiból tevődik össze. Ezt maga a turisztikai ipar és az államok turisztikai irányelvei is támogatják; azon komparatív előnyök miatt, amelyek az egyenletes és összetett turisztikai fejlesztésnek köszönhetőek, és ami miatt az Európai Unió támogatja az olyan fejlesztési programokat, mint a Leader 1-2. A természetes és az emberi környezet megörzése terén fö céljuk a turisztikai kínálat megváltoztatása és új turisztikai célpontok kijelölése. Görögország egyik legszebb természetes környezete az Olympus hegy erdős területei, a Kerkini tó, Kis- és Nagy Prespa, a Pindos hegy erdős területei, Fractos és Dadias erdei, a Nestos folyó delta területe.

A terület stratégiai fejlődése felvetődik olyan viszonylatban is, amely specializálja az általános célokat, elkülönül a helyi karakterektől és a mezögazdasági környezettöl, egy agrárturisztikai körzet létrehozásának a szándékával párosulva. Ennek az agrárturisztikai körzetnek a létrehozását az alternatív turizmus fajtáinak növekedésével, a tradicionális mezőgazdasági területek és funkcióik fejlesztésével kívánják elérni, kombinálva ezeket a lehetőségeket a helyi termelői aktivitás és szociális események nyújtotta lehetőséggel.

De hogyan tudjuk növelni az alternatív turizmus iránti keresletet? Egyik jó módszer erre a tündérmesék alkalmazása. Éveken keresztül a mesék, a zene és a mitológia motiválta az embereket az alternatív turizmusra, mivel a történetek többsége erdöben, folyópartokon, hegyekben játszódott, és a fôszzereplők gyakran állatok voltak. Ha megvizsgáljuk az alternatív turizmust, láthatjuk, hogy mindkettő - mesék és alternatív turizmus - ugyanazt a célt szolgálják, ugyanazt szeretnék: happy end-et.

\section{Alternativ turizmus}

$\mathrm{Az}$ alternatív turizmus fejlődése gyorsnak mondható világszerte, különösen a fejlett országokban.

Az alternatív turizmus fejlesztésének alapvető feltétele a környezet és a turisztikai célok védelme a helyi gazdaság fejlesztésével együtt. Az alternatív turizmus különbözik a tradicionális tömegturizmustól; célja a területek különleges természeti jellemvonásainak megnevezése és karbantartása.

Az egyik fontos ok, amiért a kormányok támogatják az alternatív turizmust, hogy a turisztikai idényt 12 hónapra növeli, és olyan potenciális területeket fedez fel, amelyek nem kapcsolódnak a tradicionális turizmushoz. Az alternativ turizmus legismertebb fajtái a kulturális és történelmi turizmus, az egészségturizmus, a kon- 
ferenciaturizmus, sportturizmus, természettel kapcsolatos turizmus (ökoturizmus, agrảrturizmus, falusi turizmus és rurális turizmus) és a szórakoztató turizmus.

A turizmus egy sokoldalú folyamat (Csikszentmihályi 1998; Maslow 2003), amely gyorsan fejlödik (Hoffman-Fainstein-Judd 2000). William és Shaw (1998) szerint a turizmus fontos szerepet játszhat mint semlegesítő eszköz azokkal a társadalmi és gazdasági problámákkal szemben, amelyekkel a vidéki területeknek küzdeniük kell. Ez az oka annak, hogy a vidéki turizmus sokrétủ állami támogatást élvez (HallJenkins 1998; Gartner 2004), hiszen köztudott, hogy a gazdasági növekedés és fejlesztés egyik motorja lehet (Rátz-Puszkó 1998). A vidéki turizmus azonban nem csodaszer (Singouridis-Fotiadis 2005), hiszen nem csak pozitiv, hanem negatív következményei is vannak (Johnson-Snepenger-Akis 1994; Mason-Cheyne 2000).

$\mathrm{Az}$ alternatív turizmus fejlődése a tömegturizmus bőségének és a turisztikai szükségletek megváltozásának egy természetes következménye az új gazdaság növekedése miatt. Ứgy tủnik, hogy a turisták már megunták az úszómedencés és egyszerủ étrendes nyaralásokat, ahol be vannak zárva a négy fal közé. Valami újat keresnek. Így vált szükségessége, hogy kicsit felélesszük a környékben rejlö tiszta lehetőségeket, hogy az odalátogatóknak eredeti vendégszeretetet, történelmi, kulturális és helyi gasztronómiai értékeket nyújtsunk.

Az új alternatív turizmusfejlődés változatos megoldást kínál a turisztikai termék fejlesztésére. Létrehoz egy modellt, amely biztosítja a természeti szépségek, a kulturális örökségek és a hagyományok megörzését. Ezen elönyökkel párhuzamosan az alternatív turizmus magas szintü szolgáltatást is nyújt a vendégeknek.

$\mathrm{Az}$ alternatív turizmus fogalmába tartozó tevékenységek változatosak, de különböző kategóriákba sorolhatók. Ilyen kategória például a falusi turizmus is. „A vidéki területeken megvalósuló magánkezdeményezések szükségessége és lehetősége sok érdekes családi és közösségi kezdeményezést eredményezett, melyek segítségével a turizmus különböző fajtái fejlödhetnek ki a vidéki területeken." (Kovács 2001)

$\mathrm{Az}$ alternatív turizmus egyik kategóriaját képezik a tematikus parkok. Ezen parkok változatossága tükrözi a kereslet sokszínűségét, például gyermekek számára létrehozott tematikus parkok, technológiai vonatkozású tematikus parkok, történelmi eseményt életre keltő tematikus parkok stb. Bár drágák, a tematikus parkok óriási növekedést mutatnak, valójában ez a legérdekesebb fajtája a mai turizmusnak. Görögországban nincsenek ugyan ilyen nagy tematikus parkok, de azok, amelyek üzemelnek, általában szórakoztatással és tengeri sportokkal foglalkoznak. Szép kezdeményezés lenne, ha gyermekek számára is létesülnének ilyen tematikus parkok, ahol a világ jelenségeiről és tényeiről mítoszokon és meséken keresztül kapnának képet.

A meséket olyankor hallgatták és hallgatják ma is, amikor a hosszú nap után az emberek hazaérnek, megpihennek, vagy a nyári tábortüz körül, esetleg hideg téli estéken a kandalló mellett ülve. Továbbá olyankor, amikor az idösebb generációk adják át bölcsességüket, gondolataikat, költészetüket és irodalmukat a fiatalabbaknak. A mesék szövege mögött mindig más idők, emberek, életek, vágyak voltak, melyeket az emberi képzelet táplált, és képesek voltak generációkat átívelően fennmaradni a mai napig anélkül, hogy bármit veszítettek volna szépségükből és varázsukból. 
A mítoszok és mesék ott keletkeztek, ahol kis csoportok összejöttek. Ilyen helyek lehettek a kunyhók, illetve a kunyhók körüli területek, települések, térségek, ahol az emberek a következő napi dolgaikat rendezgették, és ezalatt hallgatták az öregek kalandjait, meséit. Ez sokszor éjszaka történt, sötétben, petróleumlámpa világánál, ezeket nevezték virrasztásnak. Mivel a munka nehéz volt és az emberek fáradtak voltak és álmosak, a „mesemondó" feladata volt ébren tartani öket kellemes és érdekes történeteivel és meséivel.

A mese másik forrása a kávéház volt. Abban az időben, amikor még nem létezett a lemezjátszó vagy a hifi, illetve televízió sem volt, a törzsvendégek énekléssel és valós vagy képzeletbeli történetekkel szórakoztatták egymást és magukat. Az ókorban a legkedveltebb történetek nem feltétlenül a hősökről szóltak, mint például Herkules, hanem sokkal inkább olyanokról, akik valamilyen hősies tulajdonsággal bírtak, vagy hőstettet vittek véghez. Plutarchos úgy ír róluk, mint: „páratlan és legendás dolgokról szóló mesék, mondák". Hérodotosz Múzsák-ban szereplö történetei szájról szájra jártak, és néha találkoztak a társadalmi hagyományokkal, néha elvesztek a legendákban.

Tehát már tudjuk, hogy az ókori görögök nagyon szerették a meséket, erre Arisztofanész Pluto-jában is bizonyítékot találunk, amikor egy ravasz mesemondó, Pszilepsziosz pénzért kezd el meséket mondani. A Bizánci Birodalomban a mesék tovább hódítottak csöndesen. Rengeteg kedvelt mesét találhatunk abból a korból.

\section{Gyerekek és tündérmesék}

A tündérmese egy ősi irodalmi müfaj, amelyet elöször felnőtteknek írtak, de a gyerekeket sokkal inkább megérintette. A menekülés egy szükséges útja ez számukra. Egy másfajta világ tárul fel, egy varázslatos világ, ami fontos a gyerekek számára.

A mai gyerekek, akik egy technikai és fogyasztói társadalom által uralt világban élnek, amely állandóan harcban áll, verseng, állandó félelem jellemzi, szennyezett és a napi életritmus rendkívül gyors, már nem is nagyon találkoznak a tündérmesékkel, így a mese érzelmi ereje egyre fogy. Ezt csak erőteljesen elősegíti a napi sajtó, a televízió, rádió, disco, a zajos élettér és a színpadiasság. Ez a tendencia erősíti a tudományok fejlődését, az ür meghódítását, egyre nagyobb városok keletkeznek és a gépek jelenléte egyre erőteljesebb mindennapi életünkben.

\section{A tündérmese, mint az alternatív turizmus fejlesztésének eszköze}

Ha a gyerekeket rávezetjük arra, hogy régi meséket és történeteket olvassanak, érzékenyebbé tesszük őket a természeti szépségek iránt, és ezáltal a későbbiekben az alternatív turizmus számottevő fejlỏdésére számíthatunk.

Ebben segítségünkre lehetnek az alábbiakban felsoroltak:

- Állatok és madarak: a mesék nagy része kisgyerekekhez szól, ezekben házi és vadállatok szerepelnek. Ezek az emberi tulajdonságokkal felruházott állatok 
allegorikusan tanítják a gyermekeket a társadalmi szabályok betartására és megértésére, mint amilyen például a munka, az igazság és az együttmüködés. Ilyen mesék segítségével fejlődhet az ökoturizmus és az agrárturizmus.

- Az erdő: ez a figyelemfelkeltés egyik kifejezőeszköze szinte minden író számára. Az erdő az a hely, ahol sajátságos csodák történnek, tündérmesébe öltöztetve. Itt együtt léteznek az állatok, a madarak, a fák, a víz az árnyékkal és a szellemekkel. A kedvelt meséinkben, az erdóben együtt élnek a tündérek, a sárkányok, a boszorkányok, vadászkastélyok és beszélő fák. Az ilyen történetek erősítik a hegyi turizmust, az ökoturizmust és az agrárturizmust is.

- Környezetvédelem: sok mese íródott óvodáskorú gyerekeknek vagy kicsit nagyobbaknak arról, hogy az emberi lelkiismeret, általában az iparilag fejlett országokban egyre hangosabban szólongatja a társadalmat, mivel a környezet kizsákmányolása és rombolása az emberi faj fennmaradásának legfớbb gátja lehet. A mi kötelességünk megvédeni a természetet a szennyezéstöl és a tüzektỏl. Ez a gondolkodásmód átöröklődött a gyerekirodalomba is, erósítve a gyerekek szeretetét a természet iránt, és ébren tartva a lelkiismeretüket és harcos lelküket, hogy visszaköveteljék, ami az övék: a friss levegöt, a tiszta játszóteret, a tiszta tengert stb.

- Ür: az ember mindig is arról álmodott, hogy az égen száll, meghódítja és értelmezi a földet és a világegyetemet. Ikarosz egy távoli őse a mai pilótáknak és asztronautáknak. Ezek a vakmerő vágyakozások és az ürutazással kapcsolatos fejlesztések is feltüzelik a gyerek fantáziáját és tágítják a látókörét.

- Utazás: a gyerekek mindig szívesen mennek utazni. Új helyeket látnak, a természet szépségét, a hegyeket, a tengert, így is gazdagítva tudásukat. Meseszerú utazásokról szóló történetek szájról szájra terjedtek a gyerekek között.

\section{Összegzés}

Segítenünk kell a gyermekeknek megszüntetni azt a félelmet, amit a valóság megismerése vált ki belőlük. Ezt a szellemi szükségletet elégíti ki a tündérmese. Ezért a tündérmese nem csupán menekülés a valóságtól, hanem egy másik világ megalkotása is, amely ki tudja elégíteni egy gyerek szellemi igényeit.

A mesén keresztül a gyerekben vágy ébred arra, hogy kiránduljon a szüleivel, akár egy kedves vidéki faluba vagy egy kempingbe. Ezáltal megadatik neki a lehetöség, hogy lássa, érezze, hallgassa és emlékezzen, illetve kifejezze mindazokat a dolgokat, amelyeket a mesében elképzelt.

Így a mese és később az alternatív turizmus által a gyerekben kialakul egyfajta környezetszemlélet és lelkiismeret, az érdeklődési köre kitágul, tanulási vágya erósödik, és ezáltal a társadalom a magas szintú alternatív turizmus felé fordul. 
Anestis Fotiadis : A tündérmese, mint az alternatív turizmusfejlesztés egy eszköze:

Görögország példája. - Tér és Társadalom 21. évf. 2007/2. 127-132. p.

\section{Irodalom}

Ács, J.Z. (1999) Are Small Firms Important? Their Role and Impact. Dordrecht/London, Kluwer Academic Publishers, Boston.

Csikszentmihályi M. (1998) És addig éltek, amig meg nem haltak: a mindennapok minösége. Kulturtrade, Budapest.

Kovács, D. (2001) Rural Tourist Development from the Perspective of a Country in Transition. (The case of Hungary) Department of Rural Sociology, Faculty of Economics and Social Sciences.

Gartner, W. (2004) Rural tourism in the USA. - International Journal of Tourism Research. 2. 267-282. o.

Hall, C.M.-Jenkins, J. (1998) The policy dimension of rural tourism and recreation. - Tourism and recreation in rural areas. Wiley, Chichester. 19-42. 0.

Hoffman, L.M.-Fainstein, S.S.-Judd D.R. (2000) Cities and Visitors: Regulating People, Markets and City Space. Blackwell Publishers, Oxford.

Johnson, D.J.-Snepenger, J.D.-Akis, S. (1994) Residents Perceptions of Tourism Development. Annals of Tourism Research. 3. 629-642. o.

Maslow, A. (2003) A lét pszichológiája felé. Ursus Libris, Budapest.

Mason, P.-Cheyne, J. (2000) Residents' Attitudes to Proposed Tourism Development. - Annals of Tourism Research. 2. 391-411. o.

Michalkó, G. (2000) Changing Spatial Pattem of Tourism - Hungary. - Studies in Geography in Hungary. 31. Geographical Research Inst. HAS, Budapest. 241-256. o.

Rátz, T.-Puczkó, L. (1998) Rural Tourism and Sustainable Development in Hungary. -Hall, D.O'Hanlon, L. (eds.) Rural Tourism Management: Sustainable Options. International Conference, Conference Proceedings. Scottish Agricultural College, Auchincruive, Ayr, Scotland, UK. 450-464.o.

Singourindis, E.-Fotiadis, A. (2005) Social-psychological influence of Agro tourism at local communities. - Вестника Балтийской Педагогической Академии. 63. Ответственный за выпуск, проф. И.Г. Станиславская.

Williams, A.-Shaw, G. (1998) Tourism and economic development: European Experiences. Wiley, Chichester. 